\title{
Gazzâli Hakkındaki Bazı Yargıların, Ön Yargı Olmak Bakımından Denetimi
}

\section{Questioning Some of the Prejudical Convictions Concerning Al-Ghazali}

\begin{abstract}
Ayşegül DOĞRUCAN * Emrullah ZORLU **

Öz: Genel felsefe tarihi ve İslâm düşünce tarihi açısından incelediğinde Gazzâli (1056-1111) büyük bir öneme sahiptir. Bunun önemli nedeni, Gazzâli'nin felsefeyle hesaplaşma adına ona karşı çıkıp düşünce tarihinde büyük kırılmalara sebebiyet vermesidir. Bununla birlikte gerek yaşadığı dönem gerekse bulunduğu konum ve de çok yönlü bir alim olması itibariyle bu önem ciddiyetini artırmaktadır. Bu olgulardan hareketle, özellikle son yıllarda İslâm düşüncesi üzerine çalışan birçok bilgin dikkatlerini Gazzâli'ye yöneltti. Bu araştırmalar temelde şu soruların cevabını arıyordu: Gazzâli’nin felsefeyle ilişkisinin mahiyeti nedir? Onun felsefeye yönelik eleştirel tavrı, İslâm medeniyetinde felsefenin ve bilimin zayıflamasına gerçekten yol açmış mıdır? Gazzâli’nin kelâmî kaygılarından hareketle geliştirdiği refleksif düşünceler felsefe eleştirileriyle uzlaştırılabilir mi? Gazzâli felsefe düşmanı mıdır? Gazzâli’nin Batı dünyasına etkisi var mıdır, var ise nelerdir? Gazzâli hakkında geçmişten günümüze yapılan çalışmalarda ortaya çıkan farklılıkların sebepleri nelerdir? Bu tür sorunlar Gazzâli hakkında birçok radikal yargılara varılmasına sebep olmuştur. Çalışmamız Gazzâli hakkındaki ön yargıların oluşma sebepleri, bazı önemli iddiaların, ön yargıların kritik edilmesi ve değerlendirilmesini konu edinecektir.
\end{abstract}

Anahtar sözcükler: Gazzâli, Felsefe Tarihi, İslam Felsefesi, Felsefe Eleştirisi, İslam Medeniyeti, Kelâm

Abstract: Al-Ghazali (d. 1111) is of great significance when examined within the scope of philosophical history and of Islamic thought. The most important reason is that, Al-Ghazali challenged philosophy to settle accounts with it and caused great fractures in the history of philosophical thought. Moreover, this importance became more serious as he was a versatile scholarly person in the context of his period and position. For this reason many scholars working on Islamic thought have focused their attention upon AlGhazali especially in recent years. As the foundation of their investigations they have sought answers to such questions as: What is the nature of Al-Ghazali's relationship with philosophy? Did his critical attitude towards philosophy cause the weakening of philosophy and science within the context of Islamic civilization? Can the reflexive opinions Al-Ghazali developed based upon his theological concerns accommodate his philosophical criticism? Was Al-Ghazali an enemy of philosophy? Did Al-Ghazali influence the western world, and if so, to what extent? What are the reasons for the differences found in studies made of Al-Ghazali in the past and today? Such problems caused people to reach many radical convictions concerning Al-Ghazali's works. This study is concerned with the reasons for the creation of prejudice against Al-Ghazali and his works, in addition to the criticism of and evaluation of some of these important claims and prejudices.

Keywords: Al-Ghazali, history of philosophy, Islamic philosophy, criticism of philosophy, Islamic civilization, theology

\footnotetext{
* Dr. Öğr. Üyesi, Akdeniz Üniversitesi, Edebiyat Fakültesi, Felsefe Bölümü, Antalya. ayseguldogrucan@akdeniz.edu.tr, https://orcid.org/0000-0002-0735-9281

** Manevi Danışman ve Rehber, Antalya İl Müftülüğü, Antalya. zorlu.emrullah07@gmail.com, https://orcid.org/0000-00022246-4717
} 


\section{Giriş}

Gazzâli'nin hayatındaki değişimler, eserlerindeki konu ve alan çeşitliliği, özellikle fikirleri ve eserlerinin din, felsefe ve tasavvuf alanına bıraktığı etkiler, eskiden beri hem Doğuda hem Batıda birçok araştırmacının ilgi odağı haline gelmiştir. Gazzâli tutucu olarak resmedilen, radikal bir dogmatik olarak tanımlandığı halde, dogmatizm karşıtı filozoflardan imancı filozoflara kadar yelpazenin farklı renkleri tarafindan incelenmiş, fikirleri ister destekleme yoluyla, isterse reddetme yoluyla olsun, daimi olarak merkeze oturmuş bir fikir insanıdır. Müsteşriklerin son iki asır boyunca yaptığı çalışmalar arasında W.H.T Gairdner, M. Asin Palacios ve Montgomery Watt, Gazzâli düşüncesinin kelâmî boyutuna daha çok dikkat çekmişlerdir. J. Obermann, Arent J. Wensinck ve F.Griffel ise felsefi yönüne ağırlık vermişlerdir. Macdonald, Beagley gibi kişilerde onun eğitsel yönü üzerinde durmuşlardır. İslam düşünce geleneğinde ise birçok mütefekkirin kendi yaklaşımlarını, bir şekilde Gazzâli ile temellendirmeye çalışması ve bu yönüyle de asırlar sonra dahi onun "Hüccet'ül-İslâm" yani "İslâm dini konusunda kendisine başvurulması gereken en yetkin kimse" unvanıyla anılmasına sebep olacaktır.

Gazzâli, kısa olduğu kadar hareketli yaşamı ile çağının kültür coğrafyasının her alanında söz ve nüfuz sahibi olmuştur. Bunun başlıca sebebi devlet nezdinde edindiği konumla birlikte onun farklı coğrafyalardaki muhataplarının bile zihinsel ve birikimsel seviyelerine göre hitap edebilme başarısını göstermiş olmasıdır. Gazzâli çoğu kez anakronik düşünme biçimine maruz kalmış, kendinden sonraki dönemlerde dahi çağına göre eylemleri anlaşılmadığg için yargılanmış bir âlimdir. İnsanlar Gazzâli’yi yaşadığı çağın gereklerine göre yargıladığını düşünürken, yaşadığı çağ ve gerekleri çoğu zaman göz ardı edilerek, yargılanan bir Gazzâli ile karşılaşırız. Çünkü yaşadığı çağdaki teosantrik düşüncenin çoğunlukla modern literatürler tarafından karanlık ya da geri olarak tarif edilişi, Gazzâli'nin de felsefe karşıtlığının dinsel bir reddiye zeminiyle algılanmasına sebebiyet vermiştir. Mesela, Gazzâli, kendi çağı içerisinde, kendisinden 500 yıl sonra yaşamış Descartes (1596-1650) ile aynı kesinlik arayışı içerisinden felsefe eleştirisi geliştirmiş olduğu halde, Descartes felsefede yeni bir çağ başlangıcı olarak okutulurken, Gazzâli amiyane tabirle felsefenin canına okuyan adam, felsefeyi ortadan kaldıran adam sıfatına maruz kalmıştır. Hâlbuki astronomi, cebriye, riyaziye ve hendese gibi ilimler söz konusu olduğunda katı olarak betimlenen fideist tavrı, iman yerine bilgiye kesin bir teslimiyete dönüşerek, açık ve seçik bilgiye karşı çıkılamayacağını ifade eder (Gazzâli 1981, 5-6). Asıl mesele Gazzâli, o gün ve bugün anlaşılmış bir düşünür müdür? Mesela felsefeye karşı geliştirdiği itiraza itiraz eden İbn-i Rüşd(1126-1198), Gazzâli'yi doğru anlamış mıdır ve dokuz asır boyunca Gazzâli doğru tartışılmış mıdır? Yaşadığı dönemdeki siyasi, dini, iktisadi ve askeri hareketlilikler dikkate alınacak olduğunda, Ortaçağda, insanların büyük ölçüde din üzerinden yönetildiği ve sosyalleşme faaliyetlerine teosantrik açıklamalarla sevk edildiği bir dönemde, Gazzâli'nin konumu daha belirginleşecek ve ne yapmaya çalıştığ 1 anlaşılacaktır. Ne var ki: Bugünkü Gazzâli okumalarının çoğu, özellikle İslam merkezli olanlar, ister onun tarafında isterse karşısında olsun, onu sadece salt bir metin üzerinden sathi bir tarih okumacılığıyla anlamaya çalışmış, bu da onun hakkında birçok radikal yargılara varılmasına sebebiyet vermiştir. Batı okumalarının bir kısmı Gazzâli'nin hakkını teslim etmek açısından daha objektif görünmektedir. Mesela Dominicus Gundissalinus (1115-1190) Gazzâli’nin Makasıd-ı Felasife simli eserini 1145 'te çevirirken, onu felsefe karşıtı olarak değil, felsefe yorumcusu olarak çevirmiştir. Özellikle karşı çıktığı Aristoteles felsefesinin de özel bir yorumcusu olarak ele almıştır (Gazzâli 1981, 21). Ancak ülkemizdeki Batıcı bakış açısı, batı kaynaklarından sadece bir kısmıyla ilgilenirken, olumlu okumaları göz ardı ediyor gibi durmaktadır. Bu farklı bakış açılarının elbette Gazzâli'nin dalgalı ruhu ve birbirinden farklı dönemleriyle de alakası vardır. O sebeple Gazzâli'nin metot veya çıkarım açısından filozof olup olmadığının tespiti üzerine düşünmek Gazzâli tualinin üzerine atılması gereken binlerce firçadan birkaçına tekabül edecektir. 


\section{Gazzâli’nin Felsefeyle İlişkisi ve Bir Filozof Olup Olmadığı̆ Problemi}

$\mathrm{Bu}$ sorunsalın en önemli saikinin Gazzâli'nin yaşamının hiçbir evresinde ve hiçbir eserinde kendi entelektüel kimliğini filozof olarak nitelememesinden ya da kendinden önceki birçok filozofun yaptığı gibi, filozof adının kaynağını teşkil eden Antik Yunan filozoflarıyla bir benzerlik bağı yahut göndermesi yapmamasından kaynaklanıyor. İslam dünyasında Kindi ile başlayan Yunan tarzı felsefe geleneği eserlerinde bir şekilde Antik Yunan filozoflarına gönderme yapmakta ve satır arasında kendisinin de onlar gibi olduğunu vurgulamaktadır. Mesela Kindi, Aristoteles'e gönderme yaparak, gerçeği arayan için "gerçek adına bir şey getirenlere teşekkür etmemiz" gerektiğini vurgularken, bu gerçeğin bilgisine ulaştıranın din ya da milletinin önemli olmadığını söylerken, bunu "Geçmişe Şükran Borçluyuz" başlığı ile verir (Kindi 2015, 147-149) Ya da Ebu Bekir Er-Razi (2016, 198), Filozofça Yaşama başlığ1 altında Sokrates'e gönderme yaparak kendisinin ona kıyasla filozof unvanını hak etmese de felsefeyle ilgilenmeyenlere nazaran bu unvana layık olduğunu ifade ederken, aynı bölümün devamında "ulaşt1ğım bilgi düzeyi filozof adını almama yetmiyorsa, keşke bilseydim, şu çağımızda bu isme layık olan kimdir!” (Er-Razi 2016, 214) demektedir. Dolayısıyla bir bütün halinde değerlendirildiğinde, Gazzâli öncesi filozofların entelektüel kimliğiyle Antik Yunan filozoflarının entelektüel kimliği ve eylemleri arasında bir bağ kurduğu görülürken, Gazzâli'nin -muhtemelen bilinçli olarak bu isim benzerliğinden uzak durması, ardından İbn-i Rüşd'ün de bu tavrın selefleri yanında saf tutması, onun bir filozof olarak algılanmasını ve adlandırılmasını zorlaştırıcı sebepler olmuştur. Bu zorlaştırıcı durum, aynı zamanda yeni bir soruyu beraberinde getirmektedir. Felsefe tarihi içinde kendisine "filozof" diyenler mi felsefi bir etkinlik gerçekleştirmiş olacaktır? Ya da bir düşünür içinde bulunduğu zaman koşullarında kendinden önceki ya da çağdaşı felsefi etkinlikte bulunan kişileri, bilhassa yöntemsel açıdan eleştirdiğinde felsefe yapmış olmayacak mıdır, yani eleştirel duruşu onun filozof unvanı almasının önünde bir engel mi teşkil edecektir? Felsefenin yapısı gereği eleştirel bir tutumu ifade etmesi, şüphesiz ki bu soruya menfi bir cevabı zorunlu kılmaktadır. Ayrıca "bilgeliği seven" anlamına gelen "filozof"un peşinden koştuğu bilgeliğin niteliği, hali hazırda felsefe literatüründe açıklanmaya muhtaç birbirinden farklı örnekleri barındırmaktadır. Bu noktada Gazzâli için, her ne kadar kendisi kullanmasa da "filozof" unvanının kullanılmasında yapılan bir temkin, onun "bilgeliği" dolayısıyla "bilgiyi" sevmediği ve düşünme faaliyetlerinin bu tarz bir yönelimi barındırmadığını gizil olarak içerir ki, her ne kadar yaptığı çalışmalarda nihayetinde "iman" vurgusu ön plana çıkıyor olsa da, imanın yollarından emin olmaya yönelik çalışması onu hali hazırda bilginin peşinden koşan bir alim konumunda tutmuştur. Eğer imana yönelik olarak yapılan entelektüel faaliyetleri felsefe dairesinin dışına atacaksak, sadece koca bir Ortaçağ boyunca bir tane filozof olmadığını iddia etmemiz gerekeceği gibi, metafizik üzerine yapılan çalışmaları da devamında bilimi ululamadığı için reddeden, felsefeyi bilime kapı açtı̆̆ 1 müddetçe değerli gören katı bir bilimselci tavrı ön plana çıkarmış oluruz.

Başka bir neden ise onun felsefeyle ve filozoflarla hesaplaşma adına yazdığı Filozofların Tutarsızlı̆̆ (Gazzâli 2009, 2-4). Montgomery Watt ve oryantalist bakış açısının tetiklediği çok sayıda araştırmacıya göre kelâmî kaygılarla yapılan bu eleştirilerin, Gazzâli'nin gerek edindiği nüfuz ve bulunduğu konum açısından İslam dünyasında felsefeye karşı olumsuz bir tavır takınılmasına, bunun düşüncenin ve bilimin zayıflamasına sebebiyet verdiği iddia edilmektedir. Ancak Gazzâli’nin sadece kelâmî kaygıyla hareket ettiğini ileri sürmek onun olasılıklar adına ortaya koyduğu mümkün dünyalar fikrini gözden kaçırmak anlamına da gelir. Açıkçası ilahiyat kültürümüz Gazzâli'yi sadece kelamcı sıfatıyla ele alma konforuna sığınıp Batılı araştırmacılar tarafından nitelendirilmiş bu tanıma kendilerinin eseriymiş gibi sahip çıkma eğilimi gösterseler de, Gazzâli'nin kelâmî kaygı düzeyinin zorunluluk yaratması gerektiğini ancak, onun 
zorunluluklar yerine mümkün dünyalar teorisine yöneldiğini gözden kaçırmamıza sebebiyet verdiğini söyleyebiliriz. Gazzâli'ye yüklenen felsefe düşmanlığının sebeplerinden birisi de kelâmî kaygıların sonucunda felsefe ve filozof eleştirisine yönelmiş olunduğunun tespiti idi. Daha da ötesi Gazzâli'nin filozofları yirmi üç meselede eleştirdiği ve filozofların üç öğretisinin İslâm öğretileriyle ters düştüğünü ve bu filozofların dinden çıktığını söylemesi, felsefeye karşı din adına bir karşıtlığı da tetiklediği söylenmektedir. Özellikle bazı oryantalist nitelikli batılı kaynaklarda ve İslam âlemindeki batıcı veya sentezci teşebbüslerde, İslam dünyasındaki bilimin ve felsefenin gerilemesiyle alakalı başrol Gazzâli'ye verilmektedir. İslam felsefesi tarihine dair ilk kuşatıcı çalışmayı yapan Solomon Munk, 1844'te yazdığ 1 şu ifadelerle tartışmanın tonunu belirlemiştir: "Gazzâli Tehâfüt'le birlikte felsefeye öyle bir darbe vurdu ki, Doğu'da felsefe bir daha kendini toparlayamadı." (Griffel 2012, 20). E. Renan ise Gazzâli'nin felsefeye karşı katı tutumun ardından asırlar boyunca İslâm coğrafyasında felsefeye karşı bir savaş başlatıldığını söyler. I. Goldziher'e göre de o döneme gelinceye kadar zaten felsefi düşüncenin zayıfladığını Gazzâli'nin bu tutumunun da son darbeyi indirdiğini söyler (Griffel 2012, 20). İslam düşünce tarihinde ona karşı en büyük eleştiriyi de İbn-i Rüşd yapmıştır. Başta Tehâfutu't-tehâfut ve Faslu'l-makâl'da Gazzâli'nin katı eleştirilerine o da sert bir tavır takınarak cevap vermiştir. İbni Rüşd'ün gerek Aristotelesçi felsefenin en ciddi takipçisi ve açıklayıcısı olarak batıda şöhret kazanması ve Gazzâli'nin ona, hayatta olmayışı sebebiyle cevap verememesi onun bir felsefe karşıtı hatta düşmanı olarak algılanmasına sebebiyet vermiştir. İbn-i Rüşd'ün sert ve edebi açıdan gayet anlaşı1ır dille yazdığı Gazzâli eleştirisi, anlaşılır ve açık üslubundan dolayı tartışmasız bir doğru olarak algılanmıştır. Gerek Gazzâli'den 20 yıl sonra kaleme alınmış olması ve bu sebeple Gazzâli'nin cevap verme şansının olmayışı, gerekse hem Gazzâli felsefe düşmanlarının kendine bu şekilde resmedilmiş bir Gazzâli'yi sahiplenerek dayanak almaları, Gazzâli'nin felsefe düşmanlığının tesciline uzanmış, din adına felsefeyi ortadan kaldıran adam hüviyetine bürümüştür. Ancak bizim tespitimizde, Gazzâli'nin kendisinden sonraki dönemlerle anlaşılması gereken bir filozof olduğu açıktır ve bu sebeple felsefede ikilik meselesi, Gazzâli'nin felsefecilerde tespit ettiği bir mesele iken, İbn-i Rüşs $(1998,446)$ bunu reddetmektedir. Fakat felsefede ikilik meselesi, Gazzâli'den en az bir ve iki asır sonra Batı âleminin de en temel tartışması haline dönüşmüş ve gerçekliğin iki yolu, iki farklı yansıması veya iki farklı gerçeklik düşünceleri Ortaçağ Skolastiğinin sonunu getirmiştir. Gazzâli, bu açıdan, her ne kadar İbn-i Rüşd bu ikilik meselesini felsefe lehine reddetse de, durumun farkındadır ve felsefe metodolojisinin kaçınılmaz düalizm inşa edeceğini kestirmektedir. Kaldı ki modern dönemlerde Descartes'ın ruh-beden, Spinoza'nın Natura Naturans-Natura Naturata, Hobbes'un düşünüm-yayılım, Kant'ın fenomen-numen ayrımları, Gazzâli’nin daha 11. Asırda fark ettiği düalizmin zaman içinde gelişerek yüzeye çıkması olarak düşünülebilir.

Gazzâli'nin kendisini bir filozof olarak görmemesi, onun felsefeyle ilgili bir formasyona sahip olmadığı, felsefeden hiç etkilenmediği veya felsefeye hiç etkisinin bulunmadığı anlamına gelmemektedir.

"Gazzâli her sınıfa, her guruba hitap etmeyi başardı̆̆ gibi, hiçbir düşünceyi okumaktan, o düşüncelerin doğurduğu zor sorunlarla mücadele etmekten de kaçınmamıştır. O ilm hayatına başladığı andan hayatının sonuna kadar bu tutumundan vaz geçmemiştir.s Ona göre, bilinen her şey ögrenilmelidir. Onun için denilebilir ki, herhangi bir ilimden korkmak veya onları seviyesi müsait birisine öğretimini engellemek ve yasaklamak, Gazzâli'nin entelektüel kişiliği ile uyuşmaz" (Deniz 2014, 13).

Gazzâli $(1960,15)$ her şeyden önce ciddi bir felsefe okuyucusudur. Ancak felsefeyle sorununu derinleştiren mesele, bilgi-bilimsel duruş çerçevesi olduğu kadar kültürel korunum meselesi 
olarak da karşımızda belirmektedir. Büyük İskender'in Doğu-Batı arasındaki sentezci yaklaşımının tam karşısında bulunan Gazzâli, kültürel manada felsefenin kültür tasallutuna dönüşmesinden de rahatsızlık duymaktadır. O sebeple felsefe reddiyesinin altında bulunan en önemli sorun ise din meselesinden ziyade kültür meselesi gibi durmaktadır, ki Büyük İskender'in hocası Aristoteles ile hesaplaşmasına bu çerçeveden de bakılabilir. Çünkü Gazzâli'nin yaşadığı dönemde de felsefe, bugünkü bir kısım akademisyen gibi, Yunan etkinliği olarak algılanmakta olup, bu etkinliği savunmak adına kendi kültürünü yermek sorunu baş gösteriyordu. Muhtemelen Gazzâli ile Endülüs ekolü arasındaki gerilimin en önemli sebeplerinden birisi felsefenin batılı bir araç olup olmadığı sorununa bakış açısıydı. Endülüs ekolü felsefeyi Batı formuyla kabul ederken, Gazzâli bu formun Doğu kültürü içerisinde tahrif edici etkiye yol açacağının endişesini taşımaktaydı. Bu sebeple kültürü korumak konusunda da gayet titiz tutum sergilediğini, gelenekten lisana kadar sergilediği muhafazakâr tutum ile anlamaktayız. Kaldı ki günümüzde de Gazzâli'nin o yıllarda sergilediği tutumlara benzer yaklaşımlar veya sorunlar mevcuttur. Gazzâli için düşünme eylemi kimliklerin bağlamıdır ve düşünme eylemi hayat prensibinin de devamlılı̆̆ açısından gereklidir. Bu ise düşünme biçiminin ortaya koyduğu sıfatları yani nitelikleri mümkün hale getirir. Her nitelik ise aynı zamanda aidiyetleri inşa eder. Açıkçası Gazzâli aidiyetlerin sahiplenilmesi konusunda prensip tutumuna sahiptir. Gazzâli’ye göre:

"Yunan felsefesinin peşinden gidenler kendi aidiyetleri olan Müslüman toplumlarl hâkir görüp kendilerini üstün tutup dinlerini küçümsediler" (Gazzali 2009, 2).

Gazzâli'nin filozoflara karşı sert tutumunun sebebi olarak; dinin umursanmaması ve o dine inanan bir halkın ve geleneğinin küçümsenmesi biçimindeki algılaması gösterilebilir. Ancak asıl sorun henüz daha modern aidiyetlerin tariflenmediği bir dönemde baş gösteren aidiyet sorunlar1dır. Aidiyetin farklı tanımları üzerinden gerçekleşen kültür bunalımı, Gazzâli'nin çözüm aradığ bir sorundur ve dönem, teosantrik bir dönem olduğu için bu aidiyetin tanımı da bizzat Gazzâli tarafindan dinsel çerçeveden gerçekleşmektedir. Aslında kültür ve aidiyeti koruma dürtüsü sayesinde dini korumak konusundaki hassasiyeti de bir ve aynı şeye dönüşmektedir. Yani dinin kendisini korumaktan daha fazla olarak, dinin sağladığı aidiyet ve kültürü koruma çabası daha ön plandadır. Gazzâli'nin bu sert tutumunu ayrı bir tartışmanın konusu olmakla beraber burada asıl olanın Gazzâli'nin Tehâfü-el Felasife'deki eleştirilerinin tutarlılığı ve bu tenkitlerinin felsefe tarihi açısından bir değerinin olup olmadığ 1 konusu düşünce tarihi açısından önem arz etmektedir. Gazzâli'nin fillozofların yöntem konusunda bile farklı ve çelişkili olduklarını, bilgilerinin sağlam delillere dayanmadığını ve büyük ölçüde zan ifade ettiğini ve kesin bilgi vermediğini ifade eder. Burada Gazzâli Yunan felsefesinin sistemleştiricisi olarak kabul gören ve İslam felsefesinde ciddi etkiler bırakan Aristoteles'i hedef alır. Gazzâli $(2009,4)$ öğretilerinin tutarsız ve temellendirilmemiş olduğunu yargılarının incelemeye ve kesin bilgiye değil zan ve tahmine dayandığını metafizik hakkındaki yargılarını temellendirmek için matematik ve mantık ilimlerini kullanarak böylece kıt akılları aldatarak ikna ettiklerini belirtir. Gazzâli burada felsefeyi riyaziye ve mantık gibi açık-seçik bir bilgi vermemekle suçlar, onların zanna dayandığını ve kesin bir bilgi taşımadığını ifade eder. Açık ve seçik bilgi, Descartes için matematiğin sahip olduğu türden bir bilgi türüydü ki, kesin bilgi arayışı anlamına gelmekteydi. (Ülken 1983, 121). Gazzâli için de, hesabi ve geometrik burhanlar yoluyla ortaya konulan bilgiler, felsefe gibi iptal edilmeyecek meselelerdi (Doğrucan 2017, 213). Bu bağlamda Gazzâli $(1960,15)$ ilimleri altı kısma ayırır: Riyaziye, mantık, tabiîyye, ilâhiye, siyasîye ve ahlak. Bu tasnif Ortaçağ eğitim sistemindeki "septem artes liberales" yani yedi özgür sanat; "quadrivium dörtlü sanat/yol (müzik, astronomi, aritmetik, geometri)" ve "trivium üçlü sanat/yol (gramer, retorik, diyalektik)" ten farklı olarak ilâhiye ve siyasîye yer almaktadır. Yani Gazzâli insanı ve Tanrı'yı da bilimin 
konusu haline getirmiştir. Ancak burada bilginin konusu haline gelen Tanrı anlayışına rağmen, bilginin yetmediği bir iman sahası açısından fideist tavrını korumaktadır. Onun fideizm ile ilişkisi, tek taraflı yorumlamalardan değil, geçirdiği evreler ve dalgalı süreçler içerisinden açıklanmalıdır. Bir insanın bulunduğu çerçevenin en koyu halini örneklem veya tanımlama öncülü olarak alıp, bütün dönemlerde o en koyu haliyle aynıymış gibi kabul ederek, onun hayatına bu kabullenmeyi genellemek, çoğu zaman yorum hatalarımıza sebebiyet vermektedir. Ancak burada belirtmek istediğimiz husus, Ortaçağ imancıları gibi, bilgiyi doğrudan imanın altına gönderen, onu yok sayan veya değersizleştiren bir bilim tasnifine sahip olmayan Gazzâli'nin bilgiyi insan çerçevesine de, ama sezgiyle ama hikmet ile indirgeyerek açıklamak isteyen insan merkezli girişimine dikkat çekmektir. Bu sebeple siyasiye olarak isimlendirdiği bilim faaliyeti, kendisinden sonraki dönemlerde, önemli kırılma noktaları yaratacaktır. Mesela Gazzâli’nin insan fitratıyla birlikte ele aldığı idareci kavramına kendisinden üç yüz yıl sonra daha geniş mercekle bakan bir Machiavelli (1469-1572), aydınlanmacı bir insan merkezciliğin ilk ipucu olarak, kendisini Rönesans içerisinden gösterecektir.

Her şeye rağmen Gazzâli'nin esas başarısı felsefeden ayırmak istediği ilimler fikriyatı üzerinedir. Gazzâli (1960, 34-35) bu sebeple doğa ilimlerini felsefeden farklı bir satıh üzerinde tarif eder ki, aslında onun Tabiîyye olarak yaptığ 1 tasnif ise içine zoolojiden astronomiye botanikten tıbba geniş bir yelpazeyi imler. Başka bir açıdan da değerlendirildiğinde Gazzâli, aydınlanmacı Batı felsefesinin 17. ve 18. yüzyılından tam 5-6 asır kadar önce felsefe disiplininden bağımsız bir disiplini doğa ilimleri çerçevesinde açıklamaya çalışmıştır ki, bu girişim aydınlanma felsefesi ve modernite ekseninin tüm doğa ilimlerini coğrafya ilmiyle açıklamaya çalışan girişimine öncülük etmektedir. Bu manada kendisini Yunan felsefesine dayamak isteyen Batı akl1, kendisinden asırlar önce felsefe sorgulaması yapan Gazzâli ile aynı noktada benzer düşünceler ve refleksler geliştirmiş̧ir ki, bu durum aslında Ne Gazzâli'nin sandığı gibi, ne de Batı felsefesinin iddia ettiği gibi, felsefeyi salt Yunan'a ait bir etkinlik yapar. Ancak günümüzde dahi felsefeyi kültürel baskınlıkla açıklamaya çalışıp Antik Yunan ürünü görmek isteyenlerin fazlalığı mevcutken, o dönem için bu fikri yadsımak lüks olur.

Buna rağmen, yukarıda belirttiğimiz gibi bu yaklaşımıyla Gazzâli, Yunan felsefesine ve onun İslam coğrafyasındaki temsilcilerine karşı Doğu aklının temsilcisi pozisyonunda görülebilir. Söz konusu Doğu aklının bir yansımasını ya da dönem tablosunun bir parçasını, Gazzâli'nin içinde yaşadığı dönemde, Kelâm ilmi teşkil ediyordu. Gazzâli'nin hocasından aldığı kelâm öğretileri miladi 9. asırda ortaya çıkan ve büyük ölçüde Bâkıllânî (950-1013) tarafından şekillendirilen Eş'arî kelâmı oluşturuyordu. Bu öğretiler dini savunma refleksiyle hareket eden ve bundan öte geçemeyen öğretilerden ibaretti. Nitekim Gazzâli demiştir ki:

\section{“Gördüm ki: Bu ilim kendi gayesini temine kâfi geliyor. Fakat benim maksadımı temin edemiyor. İlmi kelâmın gayesi Ehli Sünnetin akidesini muhafaza etmek, onu bid'at erbabinın karıştırmasından korumaktır" (Gazzâli 1960, 15).}

Burada şu benzetme yapılabilir: Gazzâli'nin silah olarak kullanmak istediği kelâm, eski bir silahtı ve çağın güçlü silahlarına karşıllk verecek yeterlilikte değildi. Yani Müslümanların rasyonalist teolojik diyalektiği olarak da değerlendirebileceğimiz kelâm, kendi içerisindeki problemleri çözebilirdi. Fakat Gazzâli'nin felsefeyle hesaplaşması olarak ifade edilen ama gerçekte Batı düşünme stili karşısında kendi ifadesiyle, (Gazzâli, 2009:4). Müslüman avam kesimin bu kültürel işgale karşı direnmesi ve aidiyet bağlarını oluşturan en önemli unsur olarak dinin korunması adına onunla mücadeleye gireceği, Batı kaynaklı felsefeye karşı bu silahın yeniden revize ederek, kendi felsefi iklimini oluşturması gerekiyordu. Eş'ari kelâmını bu alanda geliştirdiği iddia edilse de (Ülken 1983, 120) aslında Eş'ari kelamından daha ileri noktada 
düşünme diyalektiğine doğru yol aldı. Mesela 18. yy. düşünme iklimine ait metodolojiye benzer düşünme biçimiyle soyutlama, 19. yy. felsefe iklimine benzer biçimde iki zıtliktan hareketle sonuç arayan diyalektik düşünme farklı eserlerinde, farklı biçimlerle kendisini göstermektedir. Ancak şüphesiz ki, tümeller ve tikellerin varlık tanımını kapsadığı bir dönemde tekillerden bahsediyor oluşu, Gazzâli'yi çoklu mantık skalasına yerleştirecektir ki, bu durum onu kelam ilminin de çok ötesine taşıyacaktır. Fakat yine de buna rağmen, İslamcı ve Batıcı literatürlerin ilginç bir benzerlik üzerinden, Gazzâli sadece bir kelamcıymış gibi davranma eğilimi ağır basmaktadır. Gerçi bunun sebebi Gazzâli'nin birbirinden bağımsız eserlerinde, diğer mantık sahalarından dönemsel erkenlik sebebiyle açık bahsedemeyişi ve kendi dönemsel etkinliği olarak kelam ilmini açık savunuşunu örnek verebiliriz. Burada yaptığı ilk faaliyet olarak, kelâm geleneğiyle Aristotelesçi mantığı birleştirmek için teşebbüse girmek olacaktır. Gazzâli (2013, 29-30) Mi 'yâru'l-ilm 'in' de diğer birçok eserinde kıyas mantığının faydalarını vurgular. Burada dikkat edilmesi gereken en önemli husus Aristotelesçi mantığın, Aristotelesçi ontolojiden nasıl yadsınarak benimseneceği durumudur? Nitekim Gazzâli bu ayrılmaz bütünlüğü fark etmiştir. Dolayısıyla bu girişimi aslında mantık ilmine yoğunlaşırken, Aristotelesçi metafizik ve ontolojik öğretilerin bir takım temel varsayımlarını da kabul ettiğini söyleyebiliriz. (Griffel 2012, 23). $\mathrm{Bu}$ varsayımlarının kabulü aslında felsefi geleneğin İslam kelâmı içinde yer etmesine bilfiil katkı sağlamış olacaktır. İslam düşünce tarihinde bunu yapan ilk mütekellim de Gazzâli olacaktır. Onun eserleri, özellikle kelâmî eserleri dikkatle ve bütünsel olarak incelendiğinde onun ontoloji, insan nefsi ve nübüvvete dair görüşlerinin, İbn-i Sinâ (980-1037) tarafından şekillendirilmiş olduğuna şüphe bırakmayacaktır. Buna ilave olarak Tehâfüt’teki üç felsefi öğretiye yönelik söz konusu suçlama dahi, aslında Aristotelesçi felsefenin İslam kelâmı içinde tabiileşmesinin bir parçası olarak değerlendirilmelidir (Griffel 2012, 24). Gazzâli'nin Tehâfüt’teki ifade tarzı bir nebze kelâmcıların üslubunu andırsa da felsefe telakkisi, eleştirel yöne sahiptir. Öyle ki yazar, kendisini bir kelâmcı olarak değil de bir filozof gibi gösteriyor; felsefe karşıtı bir filozof veya mevcut felsefeyi batının aleti olarak kabul etmekten dolayı felsefe karşıtı bir filozof... Burada dikkat edilmesi gereken husus felsefeyi metodoloji açısından reddetmek yerine, aidiyet bağ1 ve kültür üzerinden redde yöneliyor. Gazzâli evrensel düşünce biçiminde açık bir biçimde evrensel düşünceyi savunuyor. Hatta dinin bilimin gereklerine ters düşmemesi gerektiğini ifade ederken felsefenin göreceli tavrından rahatsız olduğunu da açık biçimde beyan ediyor. Aslında Gazzâli, felsefe tahsilinin başından beri ve hatta Nişâbûr'da hocası Cüveynî’nin dersleri dışında felsefecilerle görüşüp konuştuğu zamandan itibaren felsefeyi hakikatin anlaşılması için bir araç olarak görüyordu (Zerrinkub 2001, 159). Ancak daha önce de belirttiğimiz üzere Gazzâli, uzun uğraşlar sonucu öğrendiği felsefenin aslında hakikate ulaşmada, felsefeyi faydasız ve felsefecileri de hakikat arayışı alanında sapıtmış olarak gördü. Elbette ki Gazzâli'nin bu yaklaşımlarının dinî telakkilerinden bağımsız olduğu söylenemez. Buna rağmen İslam düşünce geleneğinde önemli bir figür olarak kabul gören İbn-i Teymiyye (1263-1328) onu eski Yunan düşüncesine aşırı sevdalı olmakla eleştirir (Musa 2018, 26). İbn-i Rüşd tarafından da felsefe karşıtı olmakla suçlanır. Yine Latin İslam felsefesinin diğer büyük temsilcisi olarak değerlendirilen İbn-i Tufeyl (1105-1186) Gazzâli'nin ciddi bir düşünür olduğunu kabul ediyor ve onun birçok eserine ulaşamadığ i için hayıflanıyordu (Zerrinkub 2001, 258). Düşünce tarihi açısından incelendiğinde Gazzâli'nin fikri hayatındaki hareketlilikler ve yaşadığı dönemdeki sosyal olgular dikkate alındığında, onu, birçok filozof ve düşünürün farklı algılamasına yol açtığı söylenebilir. Araştırmacılara düşense bu ince kırılmaları yakalamak, daha efektif bir tarih okumacılığına sevk etmektedir. Gazzâli'nin dini yaklaşım ve tutumlarının fikirlerinin değersiz ve ciddiye alınmayacağı anlamına da gelmemelidir. Aksi takdirde felsefe tarihindeki birçok filozofu bu ve benzeri yaklaşımlarından dolayı sathi bir metodik tutumla düşünce tarihinin dışında bırakılabilir.

Gazzâli Ortaçağ Avrupa'sında İbn-i Sinâ ve İbn-i Rüşd ile aynı kategoride değerlendirilmiş- 
tir. Bunun sebebi Gazzâli'nin felsefeyi anlamak adına yazdığı Makâsıdu' Felâsife'sidir. Felsefeye karşı tutum ve eleştirilerini içeren eserlerinin Avrupa'ya geç taşınması onun bir Meşşâi filozof olarak tanınmasını sağlamıştır. Keza bu felsefe karşıtı filozofun skolastik düşünce üzerinde önemli etkileri oldu. Skolastik felsefenin önemli temsilcisi olarak kabul gören Duns Scotus'un (1265-1308) bazı görüşleri Gazzâli'nin "el- İktisâd"daki fikirleri arasında benzerlikler, onun Ortaçağ felsefesi üzerindeki etkisini göstermektedir. Diğer bir belirti de Nicolas d'Autrecourt'tun (1299-1369) birçok görüşü Gazzâli ile benzerlikler göstermektedir. Bu da onun Ortaçağ felsefesine önemli etkiler yaptığını ortaya koymaktadır (Zerrinkub 2001, 258). Bu konudaki bir diğer örnek de Mayorkalı filozof olan Ramon Lull'dur. (1232-1316) Filozof olmasının yanı sıra, aynı zamanda bir teolog olan ve bütün hayatı boyunca Hıristiyanlığı yayma hevesiyle hareket eden Lull, Latince, Arapça ve Katalan dillerinde büyüklü küçüklü yaklaşı üç yüz eser vermiştir. Lull'un bu eserleri kendisine büyük bir şöhret kazandırmıştı. Mantık ve bilhassa Aristotelesçi mantığa olan ilgisi, kendisini Gazzâli'ye yönlendirmiştir. Hakikaten de popüler, doğal ve ahlaki yönlerine vurgu yaptığı mantık üzerine ilk çalışmasının adı Compendium Logicae Algazelis idi. Muhtemelen bu kitap 1275 yılı civarında yazılmışı. Aslında Compendium'un Gazzâli'yle olan bağlantısı yalnızca adından kaynaklanmıyor. Kitap, Gazzâli'nin Makâsıdu' Felâsife adlı eserinin bir uyarlamasıydı. Gazzâli'nin bu eseri büyük ihtimalle 1151 ve 1166 yılları arasında Dominicus Gundissalinus ve Toledo'da çalışan bir grup âlim tarafından Latinceye çevrilmişti. (Musa 2018, 27). Böylesi bir eser Gazzâli'nin ölümünün ardından elli seneden az bir sürede çevrildiğine göre, Bağdat ve Toledo'nun gayrı Müslim alimleri arasındaki bağlantı kayda değer şekilde canlı ve etkin olmalıdır. Lull'un Gazzâli'de çekici bulduğu şey, ikisinin de kendilerine göre peşinden gittikleri müşterek düşünsel tutkuydu. "Yine Gazzâli'nin şüpheci yaklaşımının Descartes’tan çok önce bilgilerini yeniden test etmeye çalıştı. Böylece, iman ile ilgili hakikatleri idrak konusunda aklı yetersiz buldu" (Ülken 1983, 121). B. Pascal (1623-1662) gibi bir kalbe yöneldi ve "keşf" i öne çıkardı. Gazzâli'nin bu şüphesinin Descartes'ın düşünce tarzıyla benzerliği, "kalbî ma'rifet" konusunda Pascal'ın düşüncesiyle Gazzâli'nin fikri arasındaki yakınlık ve "esas yaratılı̧" hakkında Leibniz'in (1646-1716) görüşlerinin Gazzâli'nin yaklaşımlarıyla örtüşmesi, her ne kadar onların düşüncelerini ondan almış olmalarını gerektirmiyor olsa da Gazzâli'nin düşüncesinin genişliğini ve önemini göstermektedir. (Zerrinkub 2001, 263). Gazzâli’nin sebeplik ilkesine yaptığ itirazlar şüpheciliğinin en önemli kanıtını meydana getirir, Tahafût'te yaptığı bu tenkitler beş yüz yıl sonra, Batı felsefesinde önemli bir rol oynayacak olan D. Hume'un (1711-1776) tenkitlerini hatırlatıyor (Ülken 1983, 123).

"Gazzâlî, hakikati arama yolundaki gayretleriyle kendisinden sonra hem İslâm dünyasında hem de Batı'da yaşamış birçok düşünüre örnek olmuş ve yol göstermiştir. Örneğin yöntemsel şüphesi ile Descartes'e, kalp gözü düşüncesiyle Pascal'a indeterminist düşünceleriyle Hume'a, aklin bilgi edinme gücü ve sinırlarını belirlemede Kant'a (1724-1804) önderlik etmiştir. Adı geçen düşünürlerin vermiş oldukları örneklerin bile Gazzâlî ile benzer olması, onların Gazzâlî'den haberdar olduklarını göstermektedir. Onun bu felsefesi ve yöntemi izlenseydi, İslâm dünyasinda Descartes, Kant ve hatta Husserl gibi düşünürlerin ve felsefi akımların ortaya çıkması kaçınılmazdı" (Vural 2011, 235).

Düşünce tarihi sahasında felsefî bir arkeoloji yapıldığında Gazzâli sonrasında ona yakın, benzer ve aynı olan birçok yaklaşımı görmek mümkün olacaktır. Burada Gazzâli'nin büyük ve engin bir düşünür olduğu, hatta bir filozof olduğu kaçınılmazdır. 


\section{Sonuç}

Gazzâli, bir kitabıyla, entelektüel serüveninin bir dönemiyle ve yahut bir ilim hakkındaki görüşleri ile sınırlandırılacak herhangi bir kimse değildir. Farklı dönemleri, bulunan, ilim açısından her yıl farklı entelektüel zemine doğru ulaşmaya çalışan bir alimdir. Tasavvuftan felsefeye, teolojiden bilime her sahaya yatkın gözlem sahası ve üstünde spekülasyon yapma gücü bulunan Gazzâli dönemsel okumalara sıklıkla maruz kalmış, Doğrucan'ın tabiriyle erken modernist olarak nitelendirilecek derecede olgusal düşünme biçimine yönelmiş bir düşünürdür. Sıklıkla sınırlandırılmış olması veya hakkında yapılan değerlendirmelerde hakkının çok da teslim edilmiş olmaması, Gazzâli'nin milenyumu kapsayan derecede yanlış veya eksik aktarımına sebebiyet vermiştir. Aslında kelâmî kaygılarla felsefe karşıtlığı yaptığı iddia edilen Gazzâli'nin bu tanımı kazanmasına sebep olan kendi sağlığında da karşı duruş sergilediği Batı okumaları olmuştur. Başta Montgomery Watt gibi araştırmacılar vasitasılyla felsefe karşıtı ilan edilen Gazzâli'nin bu durumuna, Sünni akait taraftarları da ilginç biçimde destek vermiş ve felsefe karşıtllı̆ 1 üzerinden ötekilerin eleştirisine karşı İslamcı grupların da sahiplenmesi ortaya çıkmıştır. Aslında Gazzâli gerçekte böyle midir? Asıl sorun buradadır. Çünkü tarihsel manada bilimler felsefeden 18. yüzyıldan itibaren ayrılmaya başlasa da, Gazzâli döneminde bilimlerin felsefe ile bir arada oluşu, dönemin dinsel düşünce alimlerini felsefe karşıtlığ 1 üzerinden bilim karşıtlığına da taşımaktaydı. Ancak dikkat edilecek olursa Gazzâli'nin Tehafüt-el Felasife'sinde belirttiği üzere felsefeyi cebir, hendese, riyaziye, astronomi gibi ilimlerden ayırmakta, evrensel doğruluk değeri, görecelilik barındıran bilginin ayrımını açıklamaktadır. Aslında ilimler 18. yy. da ayrılacak olsa da bunların metodik olarak birbirinden zaten ayrı olduğunun farkında olan Gazzâli, gerçekten oryantalist tavrın betimlediği ölçüde felsefe düşmanı mıdır? Bunun öyle olmamış olması gerektiği bu makale içinde şüphe araçsallığı gereğince uygun sorular ve kanıtlar eşlinde soruldu. Bizim kanaatimiz Gazzâli'nin sadece tekil manada bir aidiyet veya nitelikle sınırlanamayacağı düşüncesidir. Mesela sadece kelamcı diye bir kategoriye hapsedilemez bir alimdir.

Tarih boyunca Gazzâli ile ilgili değerlendirmelerinin çoğu özellikle takipçileri tarafından da bu şekilde sathi değerlendirilmiştir. Bunun başlıca meşru sebepleri arasında hayatının tüm yönleriyle anlaşılamaması, eserlerinin kronolojik olarak sıralanamaması ve Gazzâli'nin onun fikirlerini kabul edenlerin ve onun yaklaşımlarını benimsemeyenlerin radikal bir tutum takınıp, Gazzâli’yi bu şekilde sunmaları gösterilebilir. Şahsında ve eserlerinde birçok çalışmalar yapılmış olmasına rağmen Gazzâli hakkında net bir sonuca varılamamasının başlıca saikleri arasında İslam Ortaçağı, özellikle Abbasi ve Selçuklu tarihi sahasının yeterince aydınlatılamamış olması gösterilebilir. Eserlerinin hayatının hareketli dönemlerinde ortaya koyması, cemiyetin her yönüne ve kesimine hitap etmek isteyişi, Gazzâli hakkında bir yöntem krizini ortaya çıkarmıştır. Gazzâli'nin yaşamının bazı dönemlerinde stratejik davrandığı, bazen fikir değiştirdiği, bazen siyasi erkin isteği yönünde fikirler ortaya koyduğu ve her ilimin kendi dalına göre yöntem ve usul belirlemesi Gazzâli hakkında net bir fikir ortaya konmasını güçleştirmiştir. Yine Eserlerinin ve fikirlerinin genişliği, çok çeşitli alanları kapsaması ve çoğu zaman yeni düşünceler ve izahlar içermesi, araştırmacıların onun düşünce dünyasını ihata edebilmesini güçleştirmiştir. Gazzâli üzerine çalışma yapan hemen hemen her araştırmacı eserlerinde bu ve benzeri güçlüklerin olduğunu dillendirmiştir. İslam düşünce tarihinde kendisinden sonra gelip de onu dolaylı ya da doğrudan konu edinmeyen, ona atıfta bulunmayan kimse yok denecek kadar azdır. Hayatının çocukluğundan ölümüne kadar ilimle iç içe geçmesi, onu aynı zamanda güçlü ve yenilikçi bir fâkih, ciddi münazaralara ve tartışmalara giren bir kelâmcı, eleştirel yapıya sahip bir filozof, ârif bir sufî, aynı zamanda devlet nezdinde de önemli bir konuma sahip olan bir muallim ve başarılı bir yazar olarak karşımıza çıkmaktadır ki, yaşadığı asrın ve geldiği geleneğin kültürünü azamî düzeyde eserlerine yansıtmıştır. Onun felsefe karşıtı yaklaşımlarının ve söylemlerinin kendisinden sonra düşünce tarihine iz bırakmış birçok filozoflar tarafından dile 
getirilmesi, Gazzâli'nin ciddi bir düşünce adamı ve filozof olduğunu kendi çağının dahi ilerisinde olduğunu, geleceğin filozofu olduğunu bize göstermektedir. İslam düşünce tarihi açısından bakıldığında felsefi ve kelâmî terminolojinin oluşmasında birçok katkıda bulunmuştur. Bu açıdan bakıldığında Gazzâli olmadan bir İslam düşünce tarihinin olması ve yazılması özgün bir İslam felsefesinden söz edilmesi çok zor olacaktır.

Aslında Gazzâli'nin özellikle batı literatürü tarafindan felsefe düşmanı ilan edilmesinin sebebini ve bu literatürlerin bu ilanını da batı karşıtlı̆̆ 1 üzerinden sahiplenen sünni ekollerin tavrını incelemek ve sorgulamak gerekmektedir. Çünkü önyargı düzleminin oluşumunda bu iki kritik aktarım biçimi neden olmaktadır. Buna tahmini cevaplar da verilebilir, Batı'nın yönlendirmek istediği bir Doğu olup olmadığı, Gazzâli'nin felsefe karşıtı mı, yoksa Batı karşıtı mı olup olmadığı tartışılmalıdır. Şimdi bizim bu düşüncemize Doğu-Batı karşıtlığının bu kadar eski kökleri olmaması gerektiğini söyleyerek karşı çıkmak isteyen olabilir ki, buna itiraz ederiz. Çünkü, Doğu-Batı karşıtlığının en bariz biçimi haçlı seferleri ile pekişmişken, bunun rüzgarının estiği dönemlerde düşünür olan Gazzâli'den bahsetmekteyiz. O sebeple bu makalenin sonuç olarak ortaya koyduğu asıl sorun, Gazali'nin Batı karşıtlığının ne şekilde felsefe karşıtlığı olarak yorumlanıp asırlara mal edilmiş olduğu sorunudur.

\section{KAYNAKÇA}

Deniz G. (2014). “Gazzâli’yi Anlamanın Usûlü”. Diyanet İlmi Dergi (2014) 7-26.

Doğrucan M. (2017). “Gazzâli’de Erken Modernite Tespiti”. Türk Dünyası Araştırmaları Vakfi (2017) 209-218.

Ebu Bekir Er-Razi. (2016). Felsefî Risaleler. Haz. Mahmut Kaya. İstanbul 2016.

Gazzâli. (2009). Filozofların Tutarsızlı̆̆ı. Çev. M. Kaya, H. Sarığlu. İstanbul 2009.

Gazzâli. (1981). Filozofların Tutarsızlı̆̆ı. Çev. B. Karlığa. İstanbul 1981.

Gazzâli. (1960). El- Munkızu Min- Ad-Dalâl. Çev. Hilmi Güngör. Ankara 1960.

Griffel F. (2012). Gazzâli’nin Felsefi Kelâmı. Çev. İbrahim Halil Üçer. İstanbul 2012.

İbn-i Rüşd. (1998). Tutarsızlığın Tutarsızlığı. Çev. K. Işık-M. Dağ. İstanbul 1998.

Kindi. (2015). Felsefî Risaleler. Çev. Mahmut Kaya. İstanbul 2015.

Musa İ. (2018). Gazzâli ve Imgelem Poetikası. Çev. Çağla Taşkın. Ankara 2018.

Ülken H. (1983). Íslam Felsefesi. İstanbul 1983.

Vural M. (2011). Gazzâli Felsefesinde Bilgi ve Yöntem. Ankara 2011.

Zerrinkub H. (2001). Medreseden Kaçış Gazzâli’nin Hayatı, Fikirleri ve Eserleri. Çev. Hikmet Soylu. İstanbul 2001. 